\title{
CERTAIN ASPECTS OF WORKING CAPITAL IN A CONSTRUCTION COMPANY
}

\author{
Wiesław Meszek ${ }^{1}$, Marcin Polewski ${ }^{2}$ \\ Institute Structural Engineering, Division of Construction Engineering Management, \\ Poznan University of Technology, Piotrowo 5, 60-965 Poznan, Poland \\ E-mail: ${ }^{1}$ wieslaw.meszek@ikb.poznan.pl; ${ }^{2}$ marcin.polewski@ikb.poznan.pl
}

Received 12 December 2005; accepted 15 September 2006

\begin{abstract}
The article analyses the profiles of selected construction companies from the viewpoint of working capital formation and their management strategies applied to working capital. The analysis was performed on the basis of financial ratios. The conclusion is that complex working capital management requires controlling methodology to be developed. A specific character of the construction industry, including operational factors and market requirements, make working capital management a task exceeding the financial sphere, as it embraces the issues of organisation of investment processes, the organisation of production processes and logistics.
\end{abstract}

Keywords: working capital, cash conversion cycle, liquidity ratio, current assets, short term liabilities.

\section{Introduction}

One of the most important aspects of company management is maintaining of the right level of working capital. The subject literature [1] differentiates between the notions of:

1) gross working capital (GWC), reflecting the company's current assets,

2) net working capital (NWC), defined as available means used to finance company's current operations, and its current level can be calculated in the following two ways:

- from the viewpoint of capital - as a difference between stable capital and fixed assets,

- from the viewpoint of property - as a difference between current assets and short term liabilities.

From the operational point of view, the level of assets circulating within the company is primarily related to the scope of its operations. Therefore, what has the real significance in the management framework is net working capital, and this is the angle from which the article will present it.

Liquidity (i.e. capability to meet current financial needs) is tightly linked with the level of working capital, whereas from the management viewpoint, there are three areas that can be identified in this context:
- management of receivables,

- stock keeping policy,

- management of short term liabilities.

Owing to the specific character of construction industry, management processes in a construction company are largely unique. A difference in approach to working capital management is due to the following factors:

- legal and tax environment which superimposes a specific regime of accounting in construction,

- the need to observe stock limits in the logistics dimension,

- special relationships between supply logistics and organisation of production processes in construction,

- the need to compete for credit lines to pay for certain areas of construction work.

The listed elements suggest that generally conceived working capital management in a construction company goes far beyond the purely financial sphere, embracing to a large extent such issues as investment process structure and organisation, production processes of design and logistics.

No working capital optimisation method, which would take the specific character of the construction industry into consideration, has as yet been developed. 


\section{The analysis of working capital level in selected construction companies}

Management strategies and the resulting level of working capital are different in different companies. In practice, working capital can take a positive, zero, as well as negative value [2] (Fig 1).

The authors of the article have analysed six selected construction companies marked in the graphs as in the legend (Fig 2).

NWC level for the analysed construction companies has been defined as static at a given moment of time, while the definition is based on the balance sheet data. The average level of working capital for three companies, namely Mostostal S. A., Elektromontaż Płd. S. A. and Projprzem S. A., is positive: 6064, 5109 and 13649 thousand PLN respectively. In three remaining companies, i.e. Budimex S. A., Naftobudowa S. A., and Bauma S. A. it is negative: 46159, 3814 and 11244 thousand PLN respectively. Only one company has recorded a significant increase of working capital (Naftobudowa S. A.), whereas in the others the level oscillates around a certain value or, as for example with Mostostal Warszawa S. A. or Budimex S. A. decreases with a long downhill trend.

The level of working capital is presented in the graph (Fig 3).

Within the framework of the analysis of factors influencing working capital levels in the companies mentioned above, particular attention was directed towards static factors of liquidity measurement [3], including the following: a) current liquidity ratio $w_{\text {III }}$ (third degree liquidity ratio) which represents the ratio of company current assets to short term liabilities,

$$
w_{I I I}=\frac{C A}{S L}
$$

a)

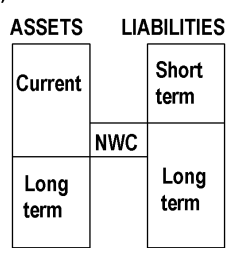

b)

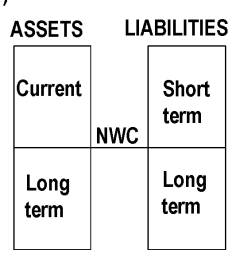

c)

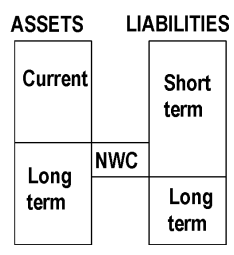

Fig 1. Working capital value levels: a) positive, b) zero, c) negative

\begin{tabular}{|c|c|}
\hline 1 & Budimex S.A. \\
\hline$-1-$ & Mostostal Warszawa S.A. \\
\hline$-1-1$ & Elektromontaż Płd. S.A. \\
\hline$--1--$ & Naftobudowa S.A. \\
\hline$\ldots \quad 1 \ldots$ & Projprzem S.A. \\
\hline$--1-1$ & Bauma S.A. \\
\hline
\end{tabular}

Fig 2. Legend: symbols representing the analysed companies shown in graphs b) quick liquidity ratio $w_{\mathrm{II}}$ (second degree liquidity ratio) which indicates the ratio of easily liquidable assets to current liabilities,

$$
w_{I I}=\frac{C A-S-P A I}{S L} ;
$$

c) cash ratio $w_{\mathrm{I}}$ (first degree liquidity ratio) indicating the share of assets which can be used immediately to solve the problem of company's short term liabilities,

$$
w_{I}=\frac{S_{m}+C}{S L} ;
$$

where: $C A$ - current assets, $S L$ - short term liabilities, $S$ stocks, $P A I$ - prepayments and accrued income, $S_{m}-$ marketable securities, $C$ - cash and cash equivalents.

The levels of $w_{I I I}$ and $w_{I I}$ ratios, which difference indicates the share of stocks in current assets, have been presented below as they changed in the analysed companies.

The value of current and quick liquidity ratios depends on the industry and its specific character. References define the limits that the ratios can take, which are $1,2 \div 2,0$ for current liquidity, and $0,9 \div 1,2$ for quick liquidity. A low level of both ratios indicates poor capability to deal with short term liabilities, whereas a high level may indicate the so called added liquidity which is a source of "lost opportunity". As to the majority of construction companies which we analyse, according to Fig 4 , the average value of $w_{I I I}$ is located between $0,75 \div 1,17$, in other words, below the recommended level. Only for Projprzem S. A. $w_{I I I}=2,28$, meaning that the upper limit of the proposed brackets is exceeded.

The quick liquidity ratio within the analysed construction companies stays within the bracket of $0,62 \div 0,99$. The average values of $w_{I I}$ for Mostostal S. A. and Elektromontaż S. A. are well inside the recommended bracket, whereas in

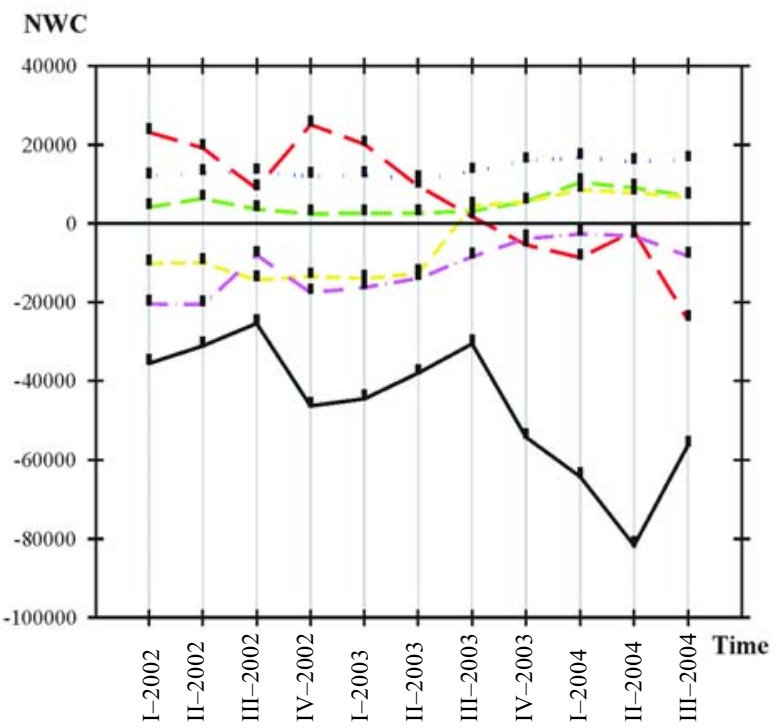

Fig 3. Working capital levels in the analysed companies 

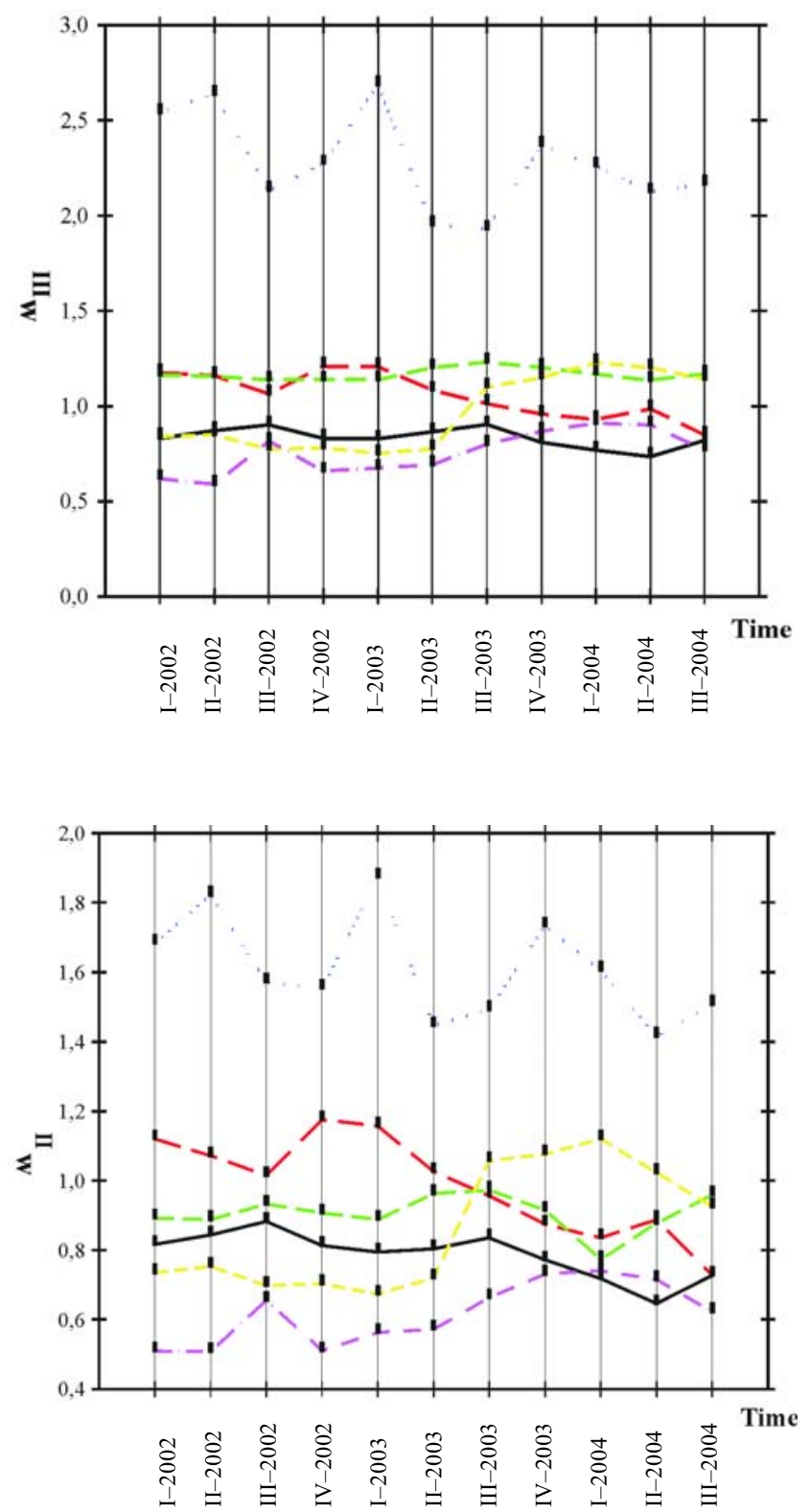

Fig 4. Levels of liquidity ratios: $\mathrm{a}$ - current, $\mathrm{b}$ - quick

Projprzem S. A. $w_{I I}=1,61$, meaning that the bracket is largely exceeded. Other companies' values of $w_{I I}$ are lower than recommended.

The notion of working capital is linked to the cycle of working of the capital (cash conversion cycle). $C C C$, or Cash Conversion Cycle is a period within which a company must engage its own financial means (net working capital) or external capital (apart from payment for its services or supplies) for funding its operations [3]. The length of the period depends on specific character of the industry, but the longer the cycle, the less economical it is for the company.

The cycles can be expressed by the following formulas [3]:

$$
C C C=O C-S T L C \text {. }
$$

The operational cycle is a sum of a stock cycle and receivables cycle [3], and is expressed by the formula below:

$$
O C=S C+R C .
$$

The stock cycle [4] is the time elapsing from the moment of purchase of raw materials to the moment of sale of finished products,

$$
S C=\frac{A S L}{P C} \times D O .
$$

Receivables cycle [4] is the time before payment for the service materialises as cash,

$$
R C=\frac{A R}{N S V} \times D O .
$$

Liabilities cycle [4] is the time needed to deal with the company's short term liabilities,

$$
S T L C=\frac{A S T L}{N S V} \times D O,
$$

where: $C C C$ - cash conversion cycle, $O C$ - operational cycle, $S T L C$ - short term liabilities cycle, $S C$ - stock cycle, $R C$ - receivables cycle, $A S L$ - average stock level, $P C$ production cost, $D O$ - number of days within the analysed period of time, $A R$ - average receivables, $N S V$ - net sales value, $A S T L$ - average short term liabilities.

Cash conversion cycles in the analysed companies are presented in Fig 5.

Working capital needs of Budimex S. A., Mostostal Warszawa S. A., Elektromontaż Płd. S. A., Projprzem S. A., determined by cash conversion cycle decreases over time, whereas in two remaining companies, namely Naftobudowa S. A. and Bauma S. A. it increases. The cash conversion cycle changes in the same direction in which the level of working capital changes, i.e. when the level of working capital

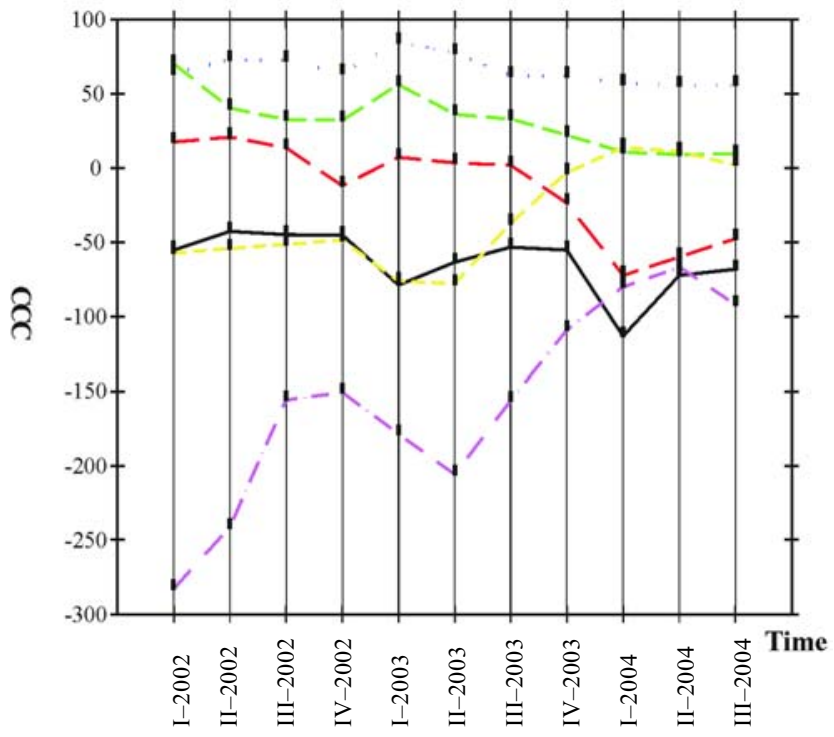

Fig 5. Cash conversion cycle in the analysed companies 
decreases, the cash cycle decreases too, and to the reverse. In construction companies with a negative conversion cycle, the liabilities cycle is definitely much longer than the receivables cycle, and the stock cycle has marginal significance. The negative value of cash conversion cycle is a proof of pathology in the construction industry, in other words, the payments are much overdue, probably regarding subcontractors, i.e. companies dependent on the main contractor. Cooperating with a contractor who has a negative cash conversion cycle is burdened with considerable hazard.

\section{Working capital management strategies}

As we have seen it until now, working capital management strategies have been perceived only in the financial aspect. There are the following strategies among many used by the companies [5]:

a) aggressive - maintaining a high short term liabilities level, and a low level of current assets in the total assets,

b) conservative - maintaining a low short term liabilities level and a high level of current assets in the total assets,

c) moderate - an intermediate strategy, somewhere between aggressive and conservative.

A given strategy is formed by partial strategies (i.e. asset and liabilities strategies) as illustrated in Fig 6. While developing a strategy for a company, it may be useful to consider the following ratios:

a) liquidity ratio $L R_{1}[1]$,

$$
L R_{1}=\frac{C+S_{m}}{C A}
$$

b) liquidity ratio $L R_{2}=w_{I}[1]$,

$$
L R_{2}=\frac{C+S_{m}}{S L}
$$

c) share of short term liabilities in total assets [4] ( $L S$ assets strategy),

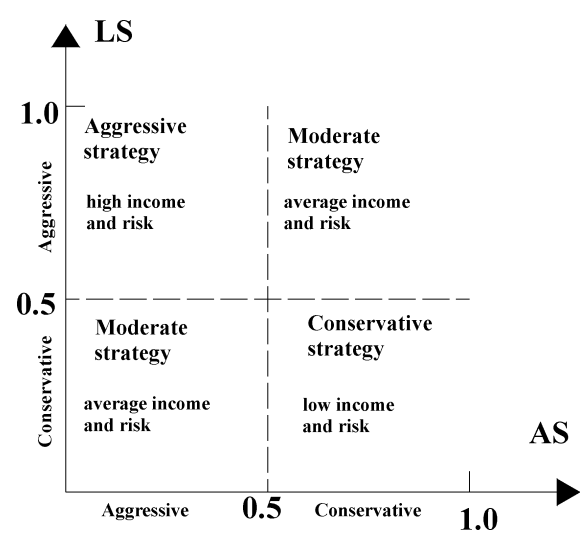

Fig 6. Working capital management strategies in a company

$$
L S=\frac{S L}{T A}
$$

d) share of current assets in total assets [4] ( $A S$ assets strategy),

$$
A S=\frac{C A}{T A},
$$

where: $T A$ - total assets.

Fig 7 and 8 illustrate the course of the above ratios in the analysed companies.

The implemented strategy of working capital management determines the structure of working capital, the way it is financed, and the level of working capital, including the cash conversion cycle. In consequence, it also influences the logistics of stock keeping policy and supplies closely related to the organisation of production processes in construction industry. It, furthermore, translates into rates of return on the capital (profit), and the inherent risk related to, among other factors, losing liquidity - Fig 6 shows the level of gain and risk. The majority of companies which
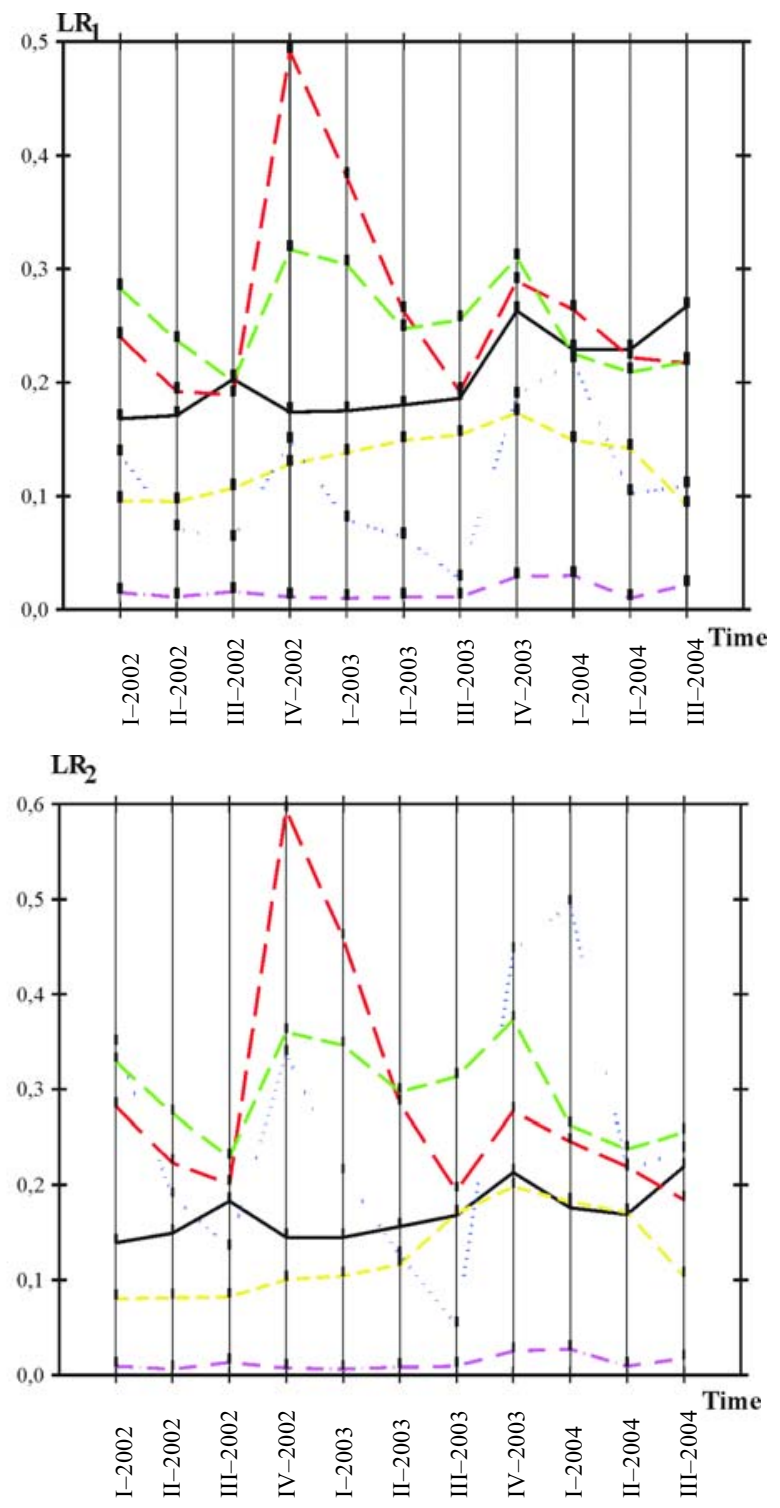

Fig 7. $L R_{1}$ and $L R_{2}$ liquidity ratios in the analysed companies 


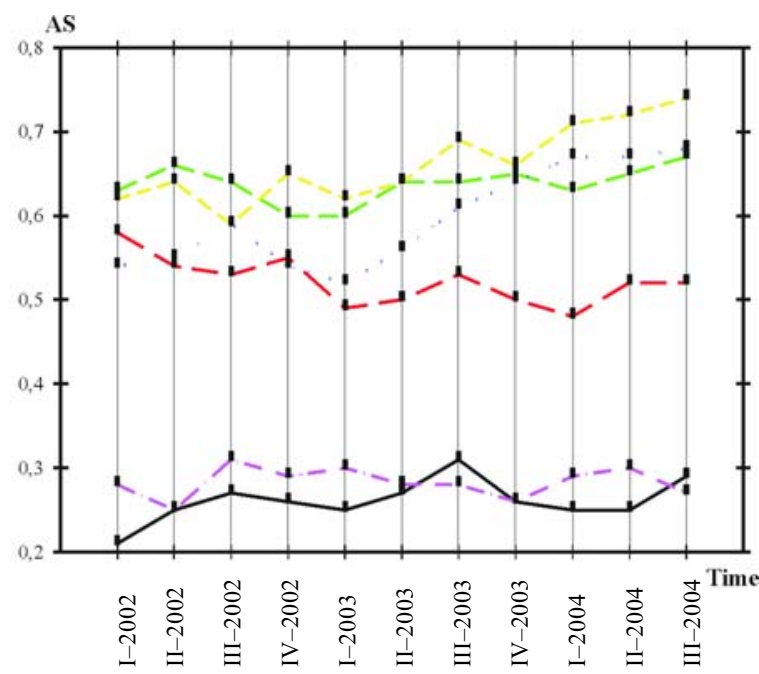

and the conservative current assets strategy. The above statement is illustrated by the average value of $L R_{1}$ and $L R_{2}$, liquidity ratios, which is kept on a low level and does not exceed $L R_{1}<0.27$ and $L R_{2}<0.30$. It practically signifies low liquidity of current assets and the possibility of paying only a part of short term dues and liabilities using the most liquid means.

\section{Conclusions}

The analysed companies operating on the construction market differ in their levels of working capital. That level is primarily influenced by the formation of partial elements and limited control over them, and does not result from a comprehensive approach to working capital.

A specific character of the construction industry and of

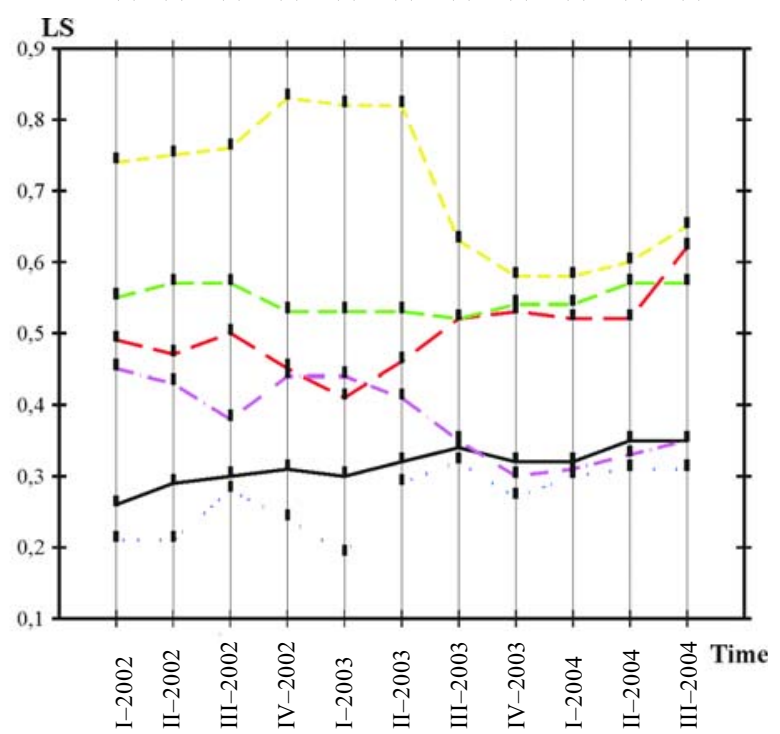

Fig 8. Share of current assets and liabilities in total assets in the analysed companies

were analysed from the angle of working capital management, opted for the moderate strategy, except for Projprzem S.A., whose policy was conservative. As to the strategy applied to the most liquid liabilities and assets, the companies preferred the aggressive short term liabilities strategy the marketplace requires the development of a methodology of working capital control which would be based not only on the instruments registering appropriate financial ratios and indices, but also on the formation of desired parameters using the knowledge of organisation of investment processes, the expertise in organising construction processes and in logistics.

\section{References}

1. Sierpińska, M.; Wędzki, D. Controlling the company's working capital. In: Penetrator. Economic News (Penetrator. Wiadomości Gospodarcze), 1995 (in Polish).

2. Pluta, W. Company's financial planning (Planowanie finansowe w przedsiębiorstwie). Warszawa: PWE, 2001 (in Polish).

3. Michalski, M. The value of liquidity in current financial management (Wartość płynności w bieżącym zarządzaniu finansami). Warszawa: CeDeWu, 2004 (in Polish).

4. Sierpińska, M.; Wędzki, D. Management of companies' financial liquidity (Zarządzanie płynnością finansową w przedsiębiorstwie). Warszawa: PWN, 1997 (in Polish).

5. Kusak, A. The right way to define working capital levels. In: Finance and Accounting Bulletin (Serwis Finansowo ksiźgowy). Infor, No 25, 2003 (in Polish).

\section{APYVARTINIO KAPITALO RODIKLIAI STATYBOS IMONĖJE}

\section{W. Meszek, M. Polewski}

\section{Santrauka}

Šiame straipsnyje, nagrinejjant finansinius rodiklius, analizuojamas pasirinktų statybos įmonių apyvartinio kapitalo formavimas ir jo valdymo strategijos. Atlikta finansinių rodiklių analizè. Daroma išvada, jog kompleksiniam apyvartiniam kapitalui valdyti turi būti sukurta kontrolès metodologija. Dėl gamybos, rinkos ir kitų veiksnių statybos pramonès i̇monėse apyvartinio kapitalo valdymas peržengia finansinę sferą, nes apima investavimo, gamybos ir aprūpinimo procesų organizavimą.

Reikšminiai žodžiai: apyvartinis kapitalas, grynujų pinigų apyvartumas, likvidumo rodiklis, dabartiniai aktyvai, galimybe įvykdyti trumpalaikius įsipareigojimus.

Wiesław MESZEK. Doctor, Associate Professor, Institute of Structural Engineering, Poznan University of Technology. Publications: 15 scientific papers. Research interests: construction management, decision - making and operations research in building production engineering, property valuation.

Marcin POLEWSKI. MSc, Assistant, Institute of Structural Engineering, Poznan University of Technology. Publications: 2 scientific papers. Research interests: construction management, quality management. 